\title{
ERROR ANALYSIS OF WORD ORDER USED IN WRITING RECOUNT TEXT MADE BY STUDENTS' AT SMK NEGERI 1 PINRANG
}

\author{
Abd. Muis Said \\ Nurul Fitrah Syams \\ English Education Department of UIN Alauddin Makassar \\ nurul.fitrab2705@gmail.com
}

\begin{abstract}
The objective of this research was to find out the kind of errors that often occurred in the use of the word order in recount text made by student at SMKN 1 Pinrang. To analyze the data, the writer used descriptive qualitative method and used error analysis procedure. The participants of this study consist of 30 students from the grade XI of Accounting 3 at SMK Negeri 1 Pinrang. The data were taken by using tests of writing. By this writing test, the writer found errors as follows: the errors of using the correct verb (45.41 percent), the errors of using the correct to be (30.28 percent) and the errors of using the correct noun phrase (24.31 percent). Based on the finding and discussion of the research, the researcher concluded that the most common error that made by the students is using verb. Based on the finding and discussion of the result, the researcher concluded that the students still faced difficulties in using word order.
\end{abstract}

KEYWORDS: Recount text, error analysis, writing, past tense, noun phrase

\section{A. INTRODUCTION}



nglish is the first foreign language taught in every school in Indonesia. Students must master four language skills. They are listening, speaking, reading and writing.

It is classified again into two parts; those are productive and receptive skills. Hamer (1991) states that in productive skills, there are speaking and writing, then in receptive skills are reading and listening. However, in this research the researcher only focuses on productive skills especially in writing. In mastering English, students find problems dealing with language skills and language components. Most students in Indonesia consider English as a difficult subject which makes them frustrated. The word order of English is different from Indonesian.

Both English and Bahasa have some different system of conventional in arranging the element of language. The form of language consists of word order, word formulation, word choice, etc. Birner (1998) states that a sentence has to have the word in order to make a sense and help us to understand the grammatical function of each constituent. According to McWhorter (2012) Some students know or have the ideas what they are going to write, but they do not know how to put them into words. They cannot build a good sentence. Many students could not express their ideas in written form, although they may know what will be written. They still could not understand or create a recount text, although the teacher had 
explained it. Most of the students are also not able to construct sentences in past tense and arrange the sentences coherently. In line with this, many students could not express their ideas smoothly in written form.

Based on the background of the study and the reason for choosing the topic, the study tries to answer this problem "What kind of errors are frequently occurred in the use of word order in recount text made by students at SMKN 1 Pinrang?" The result of this study provides evidence of how languages are learned or acquire and the strategies or procedures that used by the student. By analyzing the student, the researcher can improve the knowledge about the average of student ability.

This study is concerned on analyzing of word order used in recount text made by student at SMKN 1 Pinrang, especially in word order construction and word order distribution. In word order, construction, the researcher focused on the order of the past tense specifically in to be and verb. Whereas, in the word order distribution, the researcher wants to analyze the distribution of the word orders in the noun phrase.

\section{B. LITERATURE REVIEW}

The first study is "Grammatical Error Analysis in Recount Text Written by the Eleventh Grade of Language Class Students of MAN 1 Salatiga in Academic Year 2010/2011" by Siti Nur Rosidani (2011). In her study, the researcher examined the common errors of English grammar in recount text made by student at senior high school. The result of the study shows that the most mistake made by student are the usage of verb group, such as verb agreement, past tense, to be, past perfect tense, etc.

The second previous study was written by Nur Elah Amaliah (2012) entitled An Error Analysis on Students' Writing Recount Text a Case Study at Second Grade of SMP AlKholidin Kebayoran Baru, Jakarta Selatan. The objective of her research was to analyze the students' error in writing recount text and to know the highest frequency of the students' types of error made by Second Grade of SMP Al-Kholidin. The Errors Classification in her research covers error in Article, Capitalization, Omission, Punctuation, Spelling, Tenses, Word Choice, and Word Order. The result of the research was 5.4 percent errors in Article, 0.5 percent errors in Capitalization, 11.4 percent errors in Omission, 1.6 percent errors in Punctuation, 5.4 percent errors in Spelling, 55.4 percent errors in Tenses, 4.4 percent errors in Word Choice, 15.2 percent errors in Word Order. It can be concluded that the highest error made by students was in Tenses area and the lowest was error in Article.

The third pervious study was conducted by Nurwahid (2001) which the title is Grammatical Error Analysis of Students' Writing Recount Text a Case Study at Second grade Students of SMP Nusantara Plus. The objective of his study was to analyze the common error on students' writing made by the second grade students of Junior High School. He used Betty Schrampfer Azzar's Errors Classification to analyze the students errors. The 
research finding showed that the common kind of errors that the students made was error in Verb Tense which received 93 errors from 301 errors or 30.89 percent. The other students' error was in Add a Word which the result was 59 errors or 19.60 percent, and 33 or 10.96 percent errors in Spelling. Those were the top-three errors made by students. Most of the errors were detected caused by Interlingual Transfer which the total was 180 causes or 67.66 percent.

The fourth previous study was An Analysis of The Second Grade Students' Grammatical Errors in Writing written by Roghibah (2013) at SMP YMJ Tangerang Selatan. Her study was to analyze and to classify the types of students' grammatical errors in writing. Besides, the purpose of the study was to find out the frequency of occurrence and to find out the causes of errors which students made in paragraph. The Grammatical Error covered into six areas, namely: Tense, Subject Verb, Word Choice, Spelling, Capitalization, and Noun Phrase which adapted from Azar's Grammatical Error theory. The highest frequency was Tense which the total was 56.48 percent or 61 errors. The result of the Error Analysis process showed that students committed errors into four types: Omission, Addition, misinformation/misselection and missorder. Misinformation was the highest error made by students which the total was 62.04 percent of all the total errors made by students. Intralingual Transfer which the result was 89 or 82.40 percent was the highest cause of error of students' writing.

It can be concluded that the students stiil find difficultie in wiritng recount text or another witing types. Therefore, the researcher wants to know what kind of error that frequently occurred in the use of the word order in recount text made by student at SMKN 1 Pinrang .

Error

Corder as quotes by Kinsela (1978:63) states that "an error is typically produced by people who do not yet fully command some institution a listed language system". Based on Corder (1973:257), errors are breaking the rule, due to lack of competence such as knowledge of the language, which may or may not be conscious. As they are due to lack of competence they tend to be not correctable.

Writing

Writing has a significant function as a medium of communication to express our ideas, to share knowledge and to exchange information. As Ann Brown states that Writing is important in our lives and as a communicative act that transmit information and link people togetherll. Related to the opinion, Raymond points out that, writing is more than a medium of communication. It is a way of remembering and a way of thinking as well.

Recount text

Recount is unfolding of a sequence of events over time (Derewianka 1990:14). It is 
Abd. Muis Said \& Nurul Fitrah Syams, Error Analysis of Word Order Used in Writing Recount Text ...

about recreating past experience in using language to keep the past alive and to interpret the experience. Since recount tells about the past experiences, it uses past tenses. A recount describes events, so plenty of use is made of verbs (action words) and of adverbs to describe or add more detail to verbs.

\section{RESEARCH METHOD}

In this research, the researcher used a descriptive qualitative method which uses the procedures of error analysis. The described technique was an analysis which is aimed to describe and analyze the errors that made by the eleventh year students of SMK Negeri 1 Pinrang.

The sample of this research was XI accounting 3 class that consists of 35 students, which consist of 20 female and 15 male. The researcher took an accounting class as her sample because accounting was a favorite major in SMK Negeri 1 Pinrang.

In collecting data, the researcher asked the student to write a recount text about 150 until 200 words with a topic chosen in 100 minutes. The researcher gave a writing test for a recount text telling about the chosen topic. Then the researcher distributed the test papers to all students. When the students finished their writing, the papers collected and then the researcher circle in the incorrect words. Then, the researcher asked them to correct and revise the circling words and collecting the papers again. After all the data were collected, the researcher analyzed them.

In this research, the researcher used a test to know the common error of word order that appeared in recount text writing made by the student at SMK Negeri 1 Pinrang. Conducting research needs a process or some steps. The researcher did some procedures to conduct her research as a process. The procedures awere elaborated below:

1. The researcher needs to collect the data. Therefore, before conducting the researcher already prepare an instrument or a test for the students. The instrument/test consists of instruction to compose a recount text.

2. The researcher did her research in the class and the researcher got the class as a sample of her research based on purposive cluster sampling. The researcher gave explanation to the students, which the topic was recount text. After explaining the material, the researcher gave instruction and guidelines how doing the writing test.

3. Next, the researcher collected the students' writings test and checking it by circling the wrong words or sentences and returning it to the students to correct their writing by themselves.

4. Then, the students' writings are collected again and the researcher checked it once more to find whether the students could correct the words or not, if students could correct it that means student make a mistake and vice versa means they made an error and then the researcher identify the errors. 
5. Next, the researcher analyzed the writing test to find the errors of word order, especially in past tense and noun pharase in recount text.

6. The researcher explained the error by using the student's writing test

7. Then the researcher interpreted all of the data described. And then the researcher makes a conclusion of her research.

The researcher uses qualitative research in her study, which the method was conveyed in a descriptive analysis way to describe and to interpret the result of qualitative data. To get the qualitative result, the data calculated and drawn up in the table of percentage which the formula as follows (Bluman, 2004:68):

$$
\mathrm{P}=\frac{F}{N} \mathrm{X} 100 \%
$$

\section{FINDINGS AND DISCUSSION}

After collecting the students' task to make recount text, the writer presents the result of analyzing data in this chapter. From this data the writer identifies there were 218 sentences errors related with word order either in using verb or to be or distributing words in noun phrase committed by respondents and the data is explained below. There were many errors that the researcher found after the test but as stated in the preceding chapter that this research is focused on the kinds of errors made by the first year students of SMK Negeri 1 Pinrang on word order in past tense and noun phrases. The data was gathered by giving tests which focused on word order in past tense and noun phrases. There were 41 students on the attendance list, but there were only 30 students in the class. Some of them moved to another school, and the other did not come to school. So the researcher only took 30 students as the sample. The researcher tested the students to write recount text. The kind of errors were frequently occurred in the use of word order in recount text made by students at SMKN 1 Pinrang:

1. Verb

The students made 99 verb errors or 45.41 percent. The example is as above. The student told about her experience last ramadhan. The were three paragraphs and all the paragraphs were correctly organized based on the concept of recount text. In the first parahraph the student wrote "My Family come in my house". It should be "my Family came to my house. The researcher had marked the mistakes of the student' error but the student ignored it.

In the second paragraph the student wrote "In the first day, they are a visit in my house". The researcher had marked the mistakes of the student' error and the student corrected it but still it was wrong the student wrote "In the first day, they were a visit in my house" It should be "In the first day, they visited me in my house". In the next sentence the student wrote "I was so surprised because I do now if they are will holiday in my house. The 
researcher had marked the mistakes of the student' error and the student corrected it but still it was wrong the student wrote "I was so surprised because I the know they are will holiday in my house". It should be "I was so surprised because i didn't know that they would spend their holiday in my house". In the next sentence the student wrote "In the next day, I and my causin prepare for celebrate Ied Mubarak. The researcher had marked the mistakes of the student' error but the student recklessly didn't pay attention to it. The correct sentence should be "My cousin and I prepared to celebrate Ied Mubarak.

This was an example of a recount text written by a student where a lot of errors of word order found in using verb:

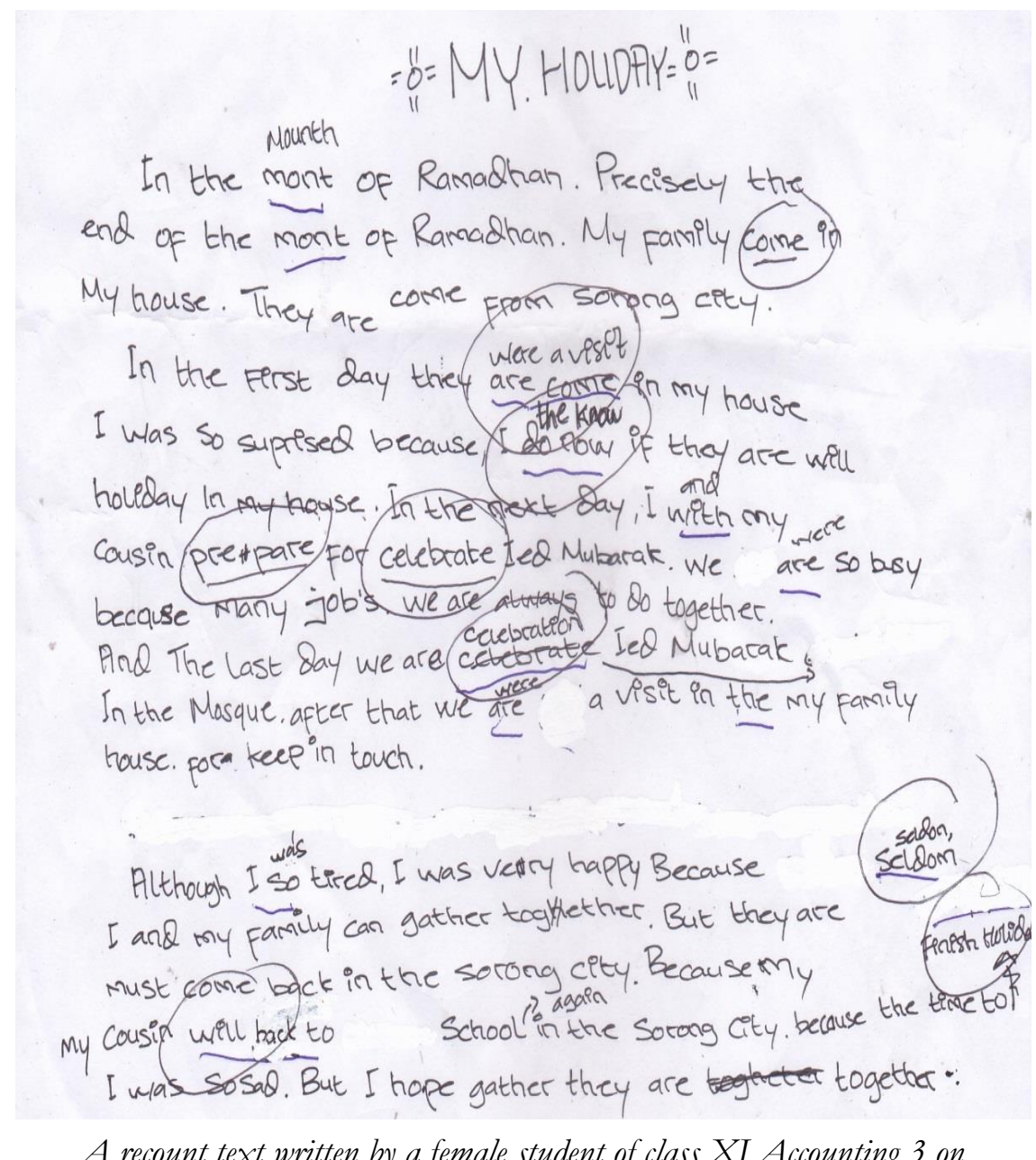

A recount text written by a female student of class XI Accounting 3 on

August $13^{\text {rd }} 2015$

After analyzed the data the writer assumed that the error caused by interlingual transfer because Bahasa has different grammatical rules from English. Verb doesn't have to change from the present to past or future and in English verb needs to change from the present to past or future to express the tense. Especially for the past verb which is divided into regular and irregular verb is confusing enough for the students because it is not available in Indonesian language. Sometimes it happened when students have learnt a rule of grammar 
and they apply it the rule for all other rules and this source of error called intralingual transfer. The students made errors in producing verb two in past form. They failed to recognize changed verb one to verb two in regular and irregular verbs.

2. To be

Most of students made error in "to be" which the error is 66 or 30.28 percent. The student told about her last experience in Galesong beach. In the first paragraph the student wrote "There are very beautiful and cool. There is a venue for visitors to the beach Galesong". The researcher had marked the mistakes of the student' error and the student corrected it but still it was wrong the student wrote "there place very beatiful and cool. There is a venue for visitors to the beach Galesong. It Should be "It was very beautiful and cool place, there was a place for visitors to visit in Galesong beach. In the next sentence the student wrote "Me and my friend to the beach to ride banana but when I ride I'm very afraid". The researcher had marked the mistakes of the student' error but the student ignored it. It should be "My friend and I went to the beach to ride banana boat but when I rode it I was very afraid."

This was an example of a recount text written by a student where a lot of errors of word order found in using to be:



A recount text written by a female student of class XI Accounting 3 on

August $13^{\text {rd }} 2015$ 
Abd. Muis Said \& Nurul Fitrah Syams, Error Analysis of Word Order Used in Writing Recount Text ...

The writer assumed that the error happened because the students didn't know how to differentiate between the use of to be for singular and plurar and also the use of to be for present and past form.

3. Noun phrase

The students made 53 noun phrase error or 24.31 percent. In the first sentence the student wrote "I don't feel this already last week, I went to house grandmother in village". The researcher had marked the mistakes of the student' error but the student ignored it. It should be "It was already a week when I went to my grandmother's house.

In the third paragraph the student wrote "Village grandmother full with chirp birds, voice winded, air fresh and many trees from not city that full with dust and smocked vehicle". The researcher had marked the mistakes of the student' error but the student ignored it. It should be "My grandmother's village was full with birds chirp, wind voice, fresh air and many trees unlike in the city there were dust and smocked vehicle".

In the fourth paragraph, the student wrote "So do I visited river in front of house's my grandmother". The researcher had marked the mistakes of the student' error but the student ignored it. It should be "I also visited the river in front of my grandmother's house".

This was an example of a recount text written by a student where a lot of errors of word order found in using to be:

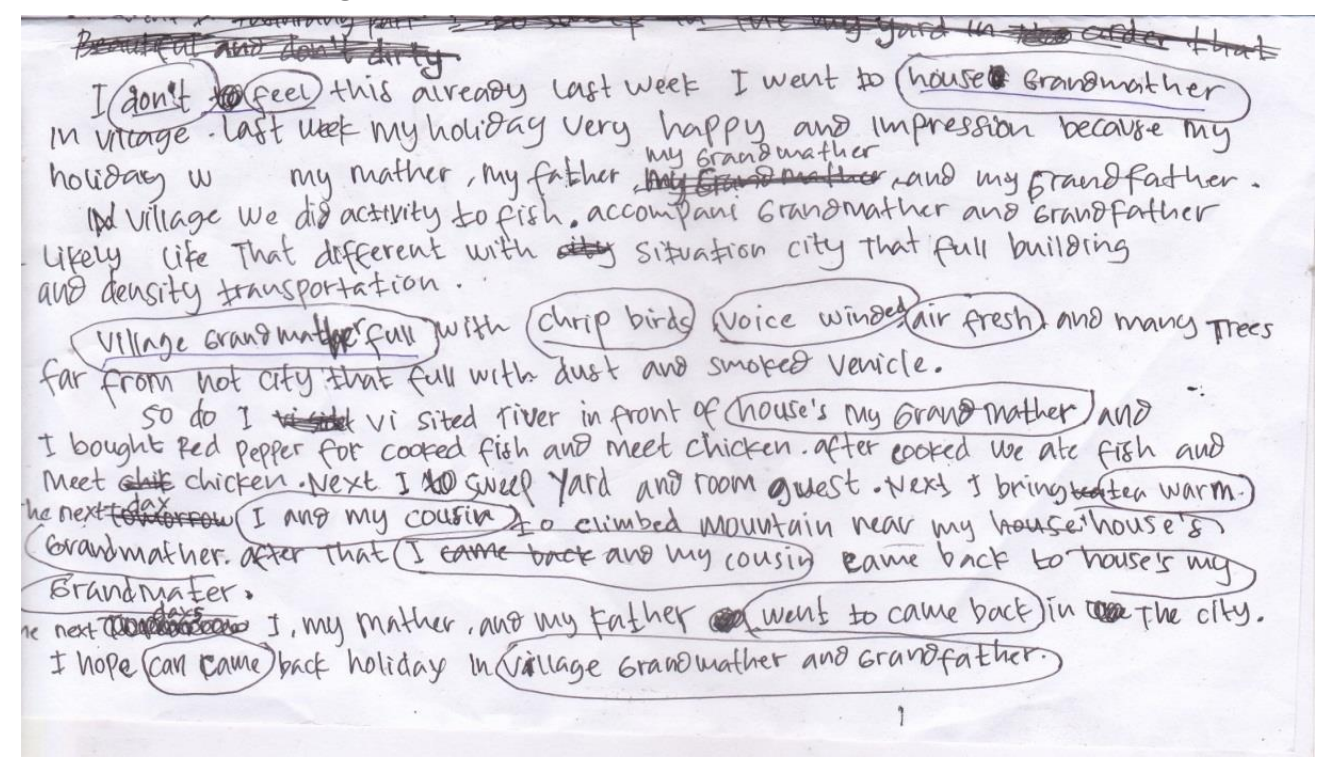

A recount text written by a male student of class XI Accounting 3 om

August $13^{\text {rd }} 2015$

The writer assumed that the error happened because the students wrote noun phrase as same as the way they wrote in bahasa. The mistake that made by the student were because the influence of their first thought about the noun phrase in Bahasa. The concept of noun phrase in Bahasa and english is different. In english, the form of noun phrase is the adjective 
is is put in front of yhe noun, different from the of noun phrase in bahasa. The form of noun phrase in bahasa is the noun put in front of the adjective. Thus. The student usually used the form of noun phrase in Bahasa so it is not suprised when they used it in English.

The precentages of the recapitulation of students' errors are converted into a pie chart. The pie chart covers the highset until the lowest rank as follows:

Figure 4.1

\section{The Students' Types of Errors}

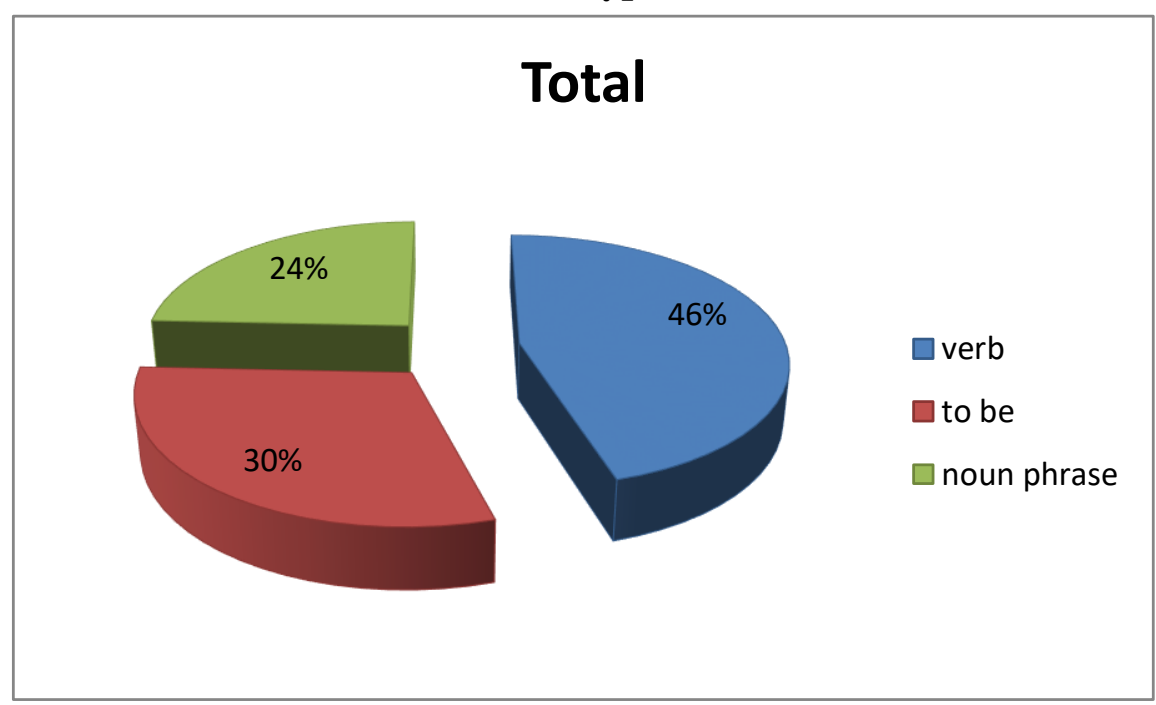

The pie chart above based on the students' writing data explains the errors that students made. The writer would like to elaborate the result of the pie chart above. The participants was 30 students. More than half or 46 percent of the students made errors in using verb. Nearly half or 30 percent of the student made errors in using to be and fourth or 24 percent of the students made errors in using noun phrase. Base on the data above, the most commont errors that the students made was using verb.

From the result of the test, the researcher found some findings of average percentage errors made by the students as follows: the error of the verb (45.41 percent), the error of to be (30.28 percent) the error of noun pharase ( 24.31 percent), It could be concluded that the most common error that made by the students is a verb. The writer is agreed with the result of the research from Nurwahid (2013) which the title is "Grammatical Error Analysis of Students' Writing Recount Text a Case Study at Second grade Students of SMP Nusantara Plus". The objective of his study was to analyze the common error on students' writing made by the second grade students of Junior High School. He used Betty Schrampfer Azzar's Errors Classification to analyze the students' errors. The research finding showed that the common kind of errors that the students made was error in Verb Tense which received 93 errors from 301 errors or 30.89 percent. The other students' error was in Add a Word which the result was 59 errors or 19.60 percent, and 33 or 10.96 percent errors in Spelling. 
But result from the researcher and result from Nurwahid above could prove that the students still faced difficulties in using word order. For example, in the researcher's result, students made an error in verb. the student wrote "after i eat, $i$ and my friends go around the street". Whereas, the correct answer is 'after $i$ ate, $i$ and my friends went around the street. Because they are confused in their mother tongue, verb doesn't have to change from the present to past or future and in English verb needs to change from the present to past or future to express the tense. Especially for the past verb which is divided into regular and irregular verb is confusing enough for the students because it is not available in Indonesian language. And the other errors commonly made by the students are noun phrase. They cannot use the correct sentence such as 'beautiful flower' most of them wrote 'flower beautiful', 'fresh air' they wrote 'air fresh', etc.

Errors in teaching learning process in Word Order are something unavoidable. Although it seems natural, students should learn more about grammar to enhance their knowledge and decreased their errors in word order. Also, the key factors that cause the error committed by respondent come from the internal of individual him/ herself. So, it is important for the teachers to pay more attention about the ability and interest of students when learning English in order for the students could improve their knowledge and they could use English better. This is appropriate with Hubbard (1983) he stated that errors could occur because of teaching material or method. If the material is well chosen, graded, and presented with meticulous care, errors could be minimized. A method that is chosen must be good in order that students feel comfortable and enjoy in receiving input from teachers.

\section{E. CONCLUSION}

Based on research finding and data interpretation in the previous chapter, the researcher found that the common kind of word order error made by the students is a verb.

The types of error that were made by the eleventh year students of SMK Negeri 1 Pinrang in their recount text writing from the highest to the lowest average percentage were error of verb (45.41 percent), error of to be (30.28 percent), and error of the noun phrase (24.31 percent),

It can be concluded that the eleventh year students of SMK Negeri 1 Pinrang still made errors in word order.

\section{F. SUGGESTIONS}

Based on conclusion above, there are some suggestions for the English teachers and for the students.

The suggestions for English teachers: (1). The teacher should give special time to the students to explain word order, especially in the use of verb because it still makes them confused. (2). The teacher should improve himself/herself in transferring the material to 
overcome students' problems in learning verb, to be and noun phrase. (3). The English teacher should be more creative in choosing strategy in teaching word order to make the students become more interested in their study. (4). The teacher should give feedback to the students' assignment in order to that the students know about the errors and mistake they have made in verb, to be and noun phrase.

The suggestions for students: (1). The students should pay more attention on word order. (2). The students must do all the test or homework given by their teacher. (3). The students should read any kinds of grammar books, especially word order to enrich their ability in understanding language structure.

The suggestion for the next researcher is in doing researh, the researcher found there were other error that the students made such as spelling and incomplete sentences. So, it could be a reference to be researched.

\section{REFERENCES}

Anderson, Mark and Kathy Anderson. Text Types in English 1. Australia: Macmillan. (1997)

Arikunto, S. Prosedur Penelitian. Jakarta: Rineka Cipta. (2010)

Azar, Betty Schrampfer. Understanding and Using English Grammar. Amerika: Longman. (1999) Barwick, John. Tergeting Text. Australia: Blake Education. (1999)

Birner, Betty J and Gregory Ward. Information Status and Noncanonical Word Order in English. Netherlands:John Banjamins Publishing Company. (1998)

Bluman, Allan G. Elementary Statistics: A step by step Approach. New York: The McGraw-Hill Companies, Inc. (2004)

Brown, Ann. Helping Children's Write. New York: Paul Chapman Publishing Ltd. (1993)

Brown, H. Douglas. Principles of Language Learning and Teaching. Fifth

Edition. New York: Pearson Education, Inc. (2007)

Celce-Murcia, Marianne and Elite Olshtain. Discourse and Context in Language Teaching. Cambridge: Cambridge University Press. (2000)

Chainstain, Kennetha. Developing Second Language Skill. Boston: Houston, Miffin Company. (1976)

Corder, S.P. Introducing Applied Linguistics. England: Penguin Education. (1973)

Derewianka, Beverly. Exploring How Texts Work. Newtown: Primary English Teaching Association. (1990)

Djuharie, OtongSetiawan. Functional English grammar. Bandung: Penerbit Rama Widya. (2008)

Ellis, R. The Study of Second Language Acquisition. Oxford: Oxford

University Press. (1997)

Erdogan, Vacide. Contribution of Error Analysis to Foreign Language Teaching.http://www.turkofoni.org/files/contribution_of_error_analysis_to_foreign_ 
Abd. Muis Said \& Nurul Fitrah Syams, Error Analysis of Word Order Used in Writing Recount Text ...

language_teaching-vac_de_erdo_an-mers_n_un_2005.pdf (2015).

Hardy, Judy and Damien Klarwein. Written Genres in the Secondary School. Brisbane: Department of Education Queensland. (1990)

Harmer, J. The Practical of English Language Teaching. London:Longman. (1991)

Hornby, Albert Sydney. Guide to Patterns and Usage in English. Oxford:Oxford University Press. (1975)

Littlefair, Allison Barbara. Reading All Types of Writing. United Kingdom:Open University Press. (1991)

McWhorter, Kathelen T. Successful College Writing: Skills-Strategies-Learning Style. Bedfort:St. Martin's. (2012)

Nichols, Ann Eljenholm. English Syntax Advanced Composition for Non-Native Speakers. United States of America: Holt, Rinehart, and Winston, Inc. (1965)

Nurwahid. "Grammatical Error Analysis of Students" Writing Recount Text (ACase Study at Second grade Students of SMP Nusantara Plus)", Skripsi in UIN Syarif Hidayatullah Jakarta: (2013)

Nur Elah Amaliah. "An Error Analysis on Students" Writing Recount Text (A Case Study at Second Grade of SMP Al-Kholidin Kebayoran Baru, Jakarta Selatan)", Skripsi in UIN Syarif Hidayatullah Jakarta: (2012)

Richards, Jack C. (Ed). Error Analysis: Perspective on Second Language

Acquisition. London: Longman. (1973)

Richards, Jack C. The Language Teaching Matrix. New York: Cambridge University Press. (1990)

-- and Willy A. Renandya. Methodology in Language Teaching: An Anthology of Current Practice.

New York: Cambridge University Press. (2002)

Roghibah. "An Analysis of the Second Grade Students" Grammatical Errors in Writing". Skeripsi in UIN Syarif Hidayatullah Jakarta: (2013).

Rosidani, Siti Nur. Grammatical Error Analysis in Recount Text Written by the Eleventh Grade of Language Class Students of MAN 1 Salatiga in Academic Year 2010/2011. Salatiga: STAIN Salatiga. (2011)

Sanal F. A Learner Based Study on Second Language Lexicology ofTurkish Students of English, Doctoral Thesis, Cukurova University. (2007)

Sugiyono. Metode Penelitian Pendidikan Pendekatan Kuanitatif, Kualitatif, dan R\&D. Bandung: Alfabet. (2008).

Wren, PC and H. Martin. High School English Grammar and Composition. New Delhi: S. Chand \& Company LTD. (1995)

Yin, Robert K. Qualitative Research from Start to Finish. New York: The Guildford Press.

http://www.thefreedictionary.com/word+order 10.54 .

http://www.collinsdictionary.com/dictionary/english/word-order 10.57 